\title{
AN INSTITUTIONAL ANALYSIS OF THE INTERNATIONAL TRADE ADMINISTRATION COMMISSION OF SOUTH AFRICA
}

\author{
Fiona Tregenna" \\ University of Johannesburg \\ ftregenna@uj.ac.za
}

Received: June 2014

\author{
Marko Kwaramba* \\ University of Johannesburg
}

kwarambamarko@gmail.com

Accepted: September 2014

\begin{abstract}
This article analyses the role and capacity of the International Trade Administration Commission of South Africa (ITAC), focusing on ITAC's tariff investigation function. ITAC's institutional setting is compared to that in other developing countries. An assessment of legal challenges to ITAC decisions shows that the proportion of ITAC's decisions overturned by the courts has declined over time, suggesting increased robustness of these decisions. ITAC's current human resources and capacitybuilding are reviewed. Key institutional issues are discussed and policy recommendations put forward concerning: the appropriate institutional location for tariff-investigations; the current positioning of ITAC under two departments; co-operation between ITAC and other institutions; the strengthening of reciprocity commitments; the role and capacity of part-time Commissioners; the duration of tariff investigations; joint capacity-building among the economic regulators; the extent to which research at ITAC should be undertaken in-house; economics and inspections capacity at ITAC; and the grading of positions at ITAC.
\end{abstract}

Keywords

Trade policy, tariffs, institutional capacity, training

\#Prof $\mathbf{F}$ Tregenna is a professor in the Department of Economics and Econometrics, University of Johannesburg, South Africa.

*Mr M Kwaramba is an affiliated lecturer in the Department of Economics and Econometrics, University of Johannesburg, South Africa. 


\section{INTRODUCTION}

This article analyses the role and capacity of the International Trade Administration Commission of South Africa (ITAC), with a view to making recommendations for enhancing the capacity and performance of the organisation. The objectives of the study are to compare ITAC's institutional setting to that in a sample of other developing countries, to evaluate the robustness of ITAC's tariff decisions to legal challenges, to assess ITAC's current human resources and capacity, and to analyse various aspects of ITAC as an institution in order to develop appropriate policy recommendations. The article is thus strongly policy-oriented.

This is a companion article to the one titled 'Analysing International Trade Administration Commission tariff investigations: case studies from poultry and paper' in this special edition. That article undertakes an assessment of ITAC's work through case studies of two specific tariff investigations, which also shed light on the issues discussed here.

ITAC was established on 1 June 2003 through the International Trade Administration Act (71 of 2002), which replaced the Board on Tariffs and Trade Act (107 of 1986). The aim of ITAC is to foster economic growth and development in order to raise incomes, promote investment and employment in South Africa and within the Common Customs Union Area (ITAC, 2013). ITAC intends to facilitate an efficient and effective system for the administration of international trade. The core functions of ITAC are customs tariff investigations, trade remedies and import and export control. To achieve these functions, ITAC is therefore composed of three main divisions or units: tariff investigations, trade remedies and import and export control. As of March 2014 it has produced 464 reports on investigations on various trade and tariff-related issues.

ITAC is a very important institution in South Africa's trade policy architecture. Tariff levels have significant economic consequences, in particular for the prices of goods for domestic consumers and the production levels, investment and employment of domestic producers. There are typically trade-offs between the economic interests of these groups in tariff levels, especially in the short to medium term, rendering the setting of tariffs a complex and sensitive exercise. The high rate of unemployment in South Africa, as well as the need for affordable basic goods for low-income consumers in particular, makes this balancing of different interests especially difficult. Tariffs set at inappropriate levels can have significant negative implications for South Africa's growth and development; thus ITAC has an important responsibility in undertaking tariff investigations and making tariff recommendations. It is thus important that tariff investigations are conducted expeditiously and use appropriate and accurate information and suitable methodologies. It is also important that tariff investigations and recommendations be both economically and legally valid, to minimise the chances of decisions being overturned through legal challenges, as such reversals are likely to be economically costly and to create uncertainty. These considerations underscore the significance of the institutional analysis of ITAC undertaken here, and the importance of policy recommendations designed to improve ITAC's role and capacity.

ITAC takes its mandate from government's trade policy. As such, changes in government policy affect ITAC's tariff investigations and recommendations. There have been distinct shifts in trade policy since the establishment of ITAC, as well as during the time of its predecessor the Board on Tariffs and Trade (BTT). ITAC periodically reviews tariff investigation guidelines to align these to government policy. Currently, ITAC is therefore following a 'developmental or strategic approach to tariff setting with the objective of promoting domestic manufacturing activity, employment 
retention and creation, and international competitiveness' (ITAC, 2013:11). Tariff decisions are evidence-based and are evaluated on a case-by-case basis. The focus here is on the tariffsetting function of ITAC rather than all the activities of ITAC.

Several methodologies were used in this research. A literature review was conducted. Various documents were sourced and analysed, both documents in the public domain and those provided to the researchers for the specific purposes of this research. A number of interviews were conducted, including with ITAC staff, government departments, experts and stakeholders. The interviews were conducted in a semi-structured manner, using a guiding set of questions while allowing for the free flow of discussion. The interviewees are listed in the Appendix. Some information sourced from the interviews was of a factual nature while other information was respondents' opinions.

The next section compares the institutional setting for tariff-setting in South Africa with that in some other developing countries. This analysis contextualises ITAC's institutional position and sheds light on possible alternative institutional arrangements. Section 3 examines the robustness of ITAC decisions in terms of legal challenges to these decisions. This is important in evaluating the performance of ITAC and in assessing possible capacity-building needs. ITAC's human resources and existing capacity-building initiatives are discussed in section 4 . Section 5 assesses some key issues facing ITAC and offers policy recommendations, as well as serving as a conclusion.

\section{INTERNATIONAL COMPARISONS OF THE INSTITUTIONAL SETTING OF TARIFF-SETTING}

What is the best way for a country to set its tariff structure and levels? There are various conceivable institutional arrangements. Tariffs could be set directly by a government department. Alternatively, this role could be mandated to an independent or semi-independent body. Apart from institutional arrangements, there are also different options as to what rules should govern the tariff-setting process, what criteria and considerations should inform decisions, and so on. The current institutional arrangements and processes for tariff-setting in South Africa represent one set of possibilities in this regard.

This section compares ITAC's tariff investigation process to the equivalent process in three other countries: Brazil, India and Pakistan. Like South Africa, these are all developing countries. The fact that two of these countries are also members of the Brazil, Russia, India, China and South Africa (BRICS) grouping renders the comparison particularly germane. This comparison is important in terms of understanding the institutional setting of ITAC and alternative possibilities in this regard. Different institutional arrangement, processes, criteria, and so on, will imply different capacity needs, so this part of the analysis also has important implications for the subsequent discussion of ITAC's capacity.

TABLE 1 provides a summary comparison of tariff investigation processes in South Africa, Brazil, India and Pakistan. The table shows the institutional setting of tariff investigations, the degree and nature of institutional 'independence', a brief summary of the process involved, and the number of days stipulated for the completion of a tariff investigation case. 
TABLE 2: International comparison of tariff-setting processes

\begin{tabular}{|c|c|c|c|c|}
\hline Country & Institutiona/ Setting & $\begin{array}{l}\text { Institutional } \\
\text { Independence }\end{array}$ & Process & Timeframe \\
\hline 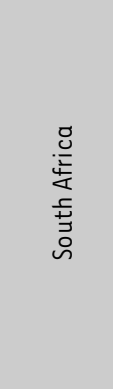 & $\begin{array}{l}\text { ITAC falls under the } \\
\text { Economic Development } \\
\text { Department (EDD) and } \\
\text { derives its trade policy } \\
\text { mandate from the } \\
\text { Department of Trade and } \\
\text { Industry (DTI). Tariff } \\
\text { changes are effected } \\
\text { through the South } \\
\text { African Revenue Service } \\
\text { (SARS). }\end{array}$ & $\begin{array}{l}\text { ITAC is independent } \\
\text { but falls under DTI }\end{array}$ & $\begin{array}{l}\text { ITAC makes } \\
\text { investigations and } \\
\text { recommends to DTI } \\
\text { which recommends } \\
\text { to Treasury and the } \\
\text { South African } \\
\text { Revenue Service } \\
\text { implements the } \\
\text { changes }\end{array}$ & $\begin{array}{l}\text { Four months for } \\
\text { sectors in distress } \\
\text { and six months for } \\
\text { normal } \\
\text { investigations }\end{array}$ \\
\hline $\begin{array}{l}\overline{\bar{N}} \\
\bar{D} \\
\bar{D}\end{array}$ & $\begin{array}{l}\text { Department of } \\
\text { International } \\
\text { Negotiations (DEINT) } \\
\text { falls under Ministry of } \\
\text { Development, Industry } \\
\text { and foreign trade (MIDC) } \\
\text { and The Board of Foreign } \\
\text { Trade (CAMEX) makes the } \\
\text { final decisions. }\end{array}$ & $\begin{array}{l}\text { DEINT is a department } \\
\text { under the Ministry of } \\
\text { Development, Industry } \\
\text { and Foreign Trade }\end{array}$ & $\begin{array}{l}\text { DEINT undertakes } \\
\text { investigations and } \\
\text { submits to CT-1 } \\
\text { which will then } \\
\text { submit to CAMEX for } \\
\text { implementation in } \\
\text { Brazil }\end{array}$ & $\begin{array}{l}\text { CAMEX Resolution } \\
\text { allows for changes } \\
\text { to be made on } 1 \\
\text { January or } 1 \text { July of } \\
\text { every year }\end{array}$ \\
\hline 음 & $\begin{array}{l}\text { Tariff Commission, } \\
\text { Ministry of Commerce } \\
\text { and Industry }\end{array}$ & $\begin{array}{l}\text { Tariff Commission is } \\
\text { Independent but falls } \\
\text { under Ministry of } \\
\text { Commerce and } \\
\text { Industry }\end{array}$ & $\begin{array}{l}\text { Tariff Commission } \\
\text { undertakes tariff } \\
\text { investigations and } \\
\text { makes } \\
\text { recommendations to } \\
\text { Ministry of } \\
\text { Commerce and } \\
\text { Industry }\end{array}$ & - \\
\hline 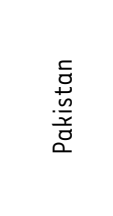 & $\begin{array}{l}\text { National Tariff } \\
\text { Commission, Ministry of } \\
\text { Commerce }\end{array}$ & $\begin{array}{l}\text { NTC is an independent } \\
\text { board but it falls under } \\
\text { Ministry of Commerce }\end{array}$ & $\begin{array}{l}\text { NTC makes } \\
\text { investigations and } \\
\text { submits its } \\
\text { recommendations to } \\
\text { Ministry of } \\
\text { Commerce }\end{array}$ & 120 days \\
\hline
\end{tabular}

Source: Authors' compilation (information sourced from the following: ITAC website: www.itac.org.za; Ministry of Development, Industry and Foreign Trade: www. mdic.gov.br; Tariff Commission website: www.tc. nic. in; and National Tariff Commission website: www.ntc.gov. pk.)

From this tabular comparison, it is evident that tariff investigations in South Africa, India and Pakistan essentially follow similar processes. The respective commissions are independent and are separate bodies that undertake investigations after which they make recommendations to the Ministry of Industry and Commerce for approval and enforcement of duties. As in South Africa, in India and Pakistan the equivalent bodies are located under the Ministries of Commerce and Industry and Commerce respectively. This allows for the respective Ministries to convey their trade and industrial policy objectives to the Commissions' tariff investigation mandate, while also time allowing the Commissions to exercise independence in conducting their investigations. 
In South Africa ITAC replaced the Board on Tariffs and Trade; similarly, the Indian Tariff Commission replaced the Tariff Board. However, an interesting aspect of the Indian Commission's institutional setting is that it was merged with the Bureau of Industrial Costs and Prices in 1999. This can allow for the timely provision of accurate information on pricing behaviour. They however both have separate Competition Commissions.

The Brazilian case is different in the sense that the Department of International Negotiations is responsible for investigating tariff changes. This is a department in the Ministry of Development, Industry and Foreign Trade. It therefore implies that it is not independent or outside of government as in the aforementioned cases. The Board of Foreign Trade (CAMEX) is responsible for making the final decisions and enforcing the changes made. Furthermore, the Brazilian case is also different in the fact that tariff changes can only be made twice a year: on 1 January or 1 July of each year.

In terms of the number of days taken to complete investigations, the Pakistan Commission is relatively fast as it takes 120 days on all cases, whereas ITAC takes between four to six months to complete investigations depending on the state of the sector concerned. In Brazil it can take up to six months to complete an investigation and effect a tariff change.

ITAC's institutional arrangements, and the merits and possibilities of shifting to an arrangement more akin to the Brazilian one, are discussed further in section 5.

\section{ROBUSTNESS OF ITAC DECISIONS TO LEGAL CHALLENGES}

The extent to which ITAC decisions hold up in court when subjected to legal challenge can be seen as an important indicator of ITAC's performance. Twenty-three ITAC decisions have been challenged in court since the establishment of ITAC in 2003. Of these 23 cases, the outcome was in favour of ITAC in twelve cases and against ITAC in seven, one was settled out of court in favour of ITAC and in a further three cases the outcome was subject to a confidentiality agreement.

Considering the trend over time, there is an improvement in the proportion of ITAC decisions that are upheld by the Courts when subjected to challenge. For the period 2004-2008, seven ITAC decisions were challenged in court, of which five went against ITAC. For the period 2009-2013, 16 ITAC decisions were challenged in court, representing a significant increase in legal challenges. However, of the 13 of these where the outcome is not subject to a confidentiality agreement, only two went against ITAC (and in one of these two cases the consequence of the order was in favour of ITAC). This trend represents an increase in the robustness of ITAC decisions when subjected to legal challenge, and indicates an improvement in ITAC's performance over time. TABLE 2 summarises the outcomes of cases in which ITAC decisions have been challenged in court. Further details on each of these cases are provided in TABLE 3 . 
Tregenna \& Kwaramba

TABLE 2: Outcomes of court challenges to ITAC decisions

\begin{tabular}{ccccc}
\hline Year & $\begin{array}{c}\text { Number of } \\
\text { cases }\end{array}$ & $\begin{array}{c}\text { Number in favour of } \\
\text { ITAC }\end{array}$ & $\begin{array}{c}\text { Number in favour of } \\
\text { applicant }\end{array}$ & Other outcome \\
\hline 2004 & 1 & 1 & 0 & \\
2006 & 3 & 1 & 2 & \\
2007 & 2 & 0 & 1 & 2 - confidentiality \\
2008 & 1 & 2 & 0 & agreement between \\
parties
\end{tabular}

Source: Derived from information provided by ITAC (In some cases the respondent was ITAC together with another institution such as SARS or the Minister of Trade and Industry. Regarding the 2012 case in which the order went against ITAC, ITAC has indicated that the consequence of the order is in favour of ITAC.)

\section{TABLE 3: Details of court challenges to ITAC decisions}

\begin{tabular}{|c|c|c|c|c|}
\hline Product & Parties & Court & Date & Outcome \\
\hline $\begin{array}{l}\text { A4 paper - 5yr expiry } \\
\text { date }\end{array}$ & Progress Office vs ITAC/Min & High Court & 2004 & In favour of ITAC \\
\hline $\begin{array}{l}\text { Carbon Black - export } \\
\text { price in sunset reviews }\end{array}$ & Algorax vs ITAC/Min & High Court & 2006 & $\begin{array}{l}\text { In favour of } \\
\text { Algorax - ITAC } \\
\text { ordered to } \\
\text { reconsider } \\
\text { recommendation }\end{array}$ \\
\hline $\begin{array}{l}\text { Shock tubes - } \\
\text { termination of } \\
\text { investigation }\end{array}$ & AEL vs ITAC & High Court & 2006 & $\begin{array}{l}\text { In favour of } A E L- \\
\text { ITAC ordered to re- } \\
\text { initiate } \\
\text { investigation }\end{array}$ \\
\hline Electric Cable & $\begin{array}{l}\text { Association of Electric } \\
\text { Cable Manufacturers vs } \\
\text { ITAC }\end{array}$ & High Court & 2006 & In favour of ITAC \\
\hline $\begin{array}{l}\text { Lysine-imposition of } \\
\text { provisional measures }\end{array}$ & Degussa vs ITAC & High Court & 2007 & $\begin{array}{l}\text { In favour of } \\
\text { Degussa: Interim } \\
\text { order and }\end{array}$ \\
\hline
\end{tabular}




\begin{tabular}{|c|c|c|c|c|}
\hline Product & Parties & Court & Date & Outcome \\
\hline & & & & $\begin{array}{l}\text { therefore no } \\
\text { precedent. }\end{array}$ \\
\hline A4 paper & Progress Office vs ITAC/Min & Supreme Court & 2007 & $\begin{array}{l}\text { In favour of } \\
\text { Progress Office }\end{array}$ \\
\hline $\begin{array}{l}\text { Wire Rope - interdict } \\
\text { to recommend } \\
\text { termination of duties } \\
\text { to Minister }\end{array}$ & Scaw vs ITAC/Min & High Court & 2008 & In favour of Scaw \\
\hline $\begin{array}{l}\text { Wire Rope - } \\
\text { separation of powers }\end{array}$ & ITAC vs Scaw & $\begin{array}{l}\text { Constitutional } \\
\text { Court }\end{array}$ & 2009 & In favour of ITAC \\
\hline $\begin{array}{l}\text { Unlawfully imported } \\
\text { trucks seized }\end{array}$ & $\begin{array}{l}\text { Clear Enterprise v } \\
\text { ITAC/SARS }\end{array}$ & High Court & 2009 & In favour of ITAC \\
\hline $\begin{array}{l}\text { Tyres - market } \\
\text { economy status }\end{array}$ & SATMC vs ITAC/Min & High Court & 2010 & In favour of SATMC \\
\hline Tyres & ITAC/Min vs SATMC & Supreme Court & 2010 & In favour of ITAC \\
\hline $\begin{array}{l}\text { Tyres - claim for } \\
\text { damages }\end{array}$ & SATMC vs ITAC & High Court & 2010 & In favour of ITAC \\
\hline $\begin{array}{l}5 \text { year expiry date - } \\
\text { declaratory judgement }\end{array}$ & ITAC/0thers vs 74 others & High Court & 2010 & In favour of ITAC \\
\hline $\begin{array}{l}\text { Wire Rope - } \\
\text { confidentiality }\end{array}$ & Scaw vs ITAC/others & High Court & 2010 & $\begin{array}{l}\text { Confidentiality } \\
\text { agreement } \\
\text { between parties }\end{array}$ \\
\hline $\begin{array}{l}\text { Wire Rope - } \\
\text { confidentiality }\end{array}$ & Casar vs ITAC/others & High Court & 2010 & $\begin{array}{l}\text { Confidentiality } \\
\text { agreement } \\
\text { between parties }\end{array}$ \\
\hline Copper scrap & Sungwong/ ITAC & High Court & 2010 & In favour of ITAC \\
\hline $\begin{array}{l}\text { Wire Rope - } \\
\text { confidentiality }\end{array}$ & Bridon vs ITAC/others & Supreme Court & 2011 & $\begin{array}{l}\text { Confidentiality } \\
\text { agreement } \\
\text { between parties }\end{array}$ \\
\hline 5 -year expiry date & Aranda/others vs ITAC/Min & High Court & 2012 & In favour of ITAC \\
\hline 5 -year expiry date & AMIE v ITAC/Others & Supreme Court & 2012 & $\begin{array}{l}\text { In favour of AMIE } \\
\text { (but the } \\
\text { consequence of } \\
\text { the order is in } \\
\text { favour of ITAC) }\end{array}$ \\
\hline $\begin{array}{l}\text { Determination and } \\
\text { confidentiality of } \\
\text { information }\end{array}$ & AMIE v ITAC & High Court & 2013 & $\begin{array}{l}\text { Settled out of } \\
\text { court in favour of } \\
\text { ITAC }\end{array}$ \\
\hline $\begin{array}{l}\text { Price Preference- } \\
\text { interdict from } \\
\text { implementing the } \\
\text { guidelines }\end{array}$ & MRA v ITAC/Min & High Court & 2013 & In favour of ITAC \\
\hline $\begin{array}{l}\text { Sugar-interdict from } \\
\text { finalising the }\end{array}$ & ASASI v ITAC & High Court & 2013 & In favour of ITAC \\
\hline
\end{tabular}

finalising the 


\begin{tabular}{lllll}
\hline \multicolumn{1}{c}{ Product } & Parties & Court & Date & Outcome \\
\hline investigation & & & & \\
Scrap metal permit & SA Metal Group v ITAC & High Court & 2013 & In favour of ITAC \\
\hline
\end{tabular}

Source: Information provided by ITAC.

Of the seven cases in which ITAC's decision was overturned by the courts (that is, the courts ruled in favour of the applicant), in two of these the issue was essentially procedural. In a further two cases the matter was around differing interpretations of the law, in one case the issue concerned the interpretation of information and method of calculation used by ITAC, and one case involved both the interpretation of the law and the interpretation of information and method of calculation used by ITAC.

While it would be ideal to have no successful legal challenges against ITAC decisions, in practice there will inevitably be differing interpretations of the law and of appropriate economic methodologies. The number of cases in which ITAC's decision was overturned by the courts is small, and decreasing over time. Enhanced legal capacity may be relevant in minimising challenges to or the eventual overturn of decisions on procedural grounds and on matters of legal interpretation, while enhanced capacity in economic analysis may be helpful regarding challenges related to methods of calculation and related issues.

\section{ASSESSMENT OF ITAC CURRENT HUMAN RESOURCES AND CAPACITY- BUILDING}

\subsection{ITAC staff structure and human resources}

The Chief Commissioner is the Chief Executive Officer and head of ITAC. The Chief Commissioner is assisted by a Deputy Chief Commissioner (currently vacant) and up to 10 part-time Commissioners. There are Senior Managers responsible for specific areas, a Chief Economist, as well as managers, senior investigators, investigators, administrators and secretaries. ITAC currently employs 154 staff in total. Of these, $54 \%$ hold degree-level qualifications. FIGURE 1 illustrates the educational qualifications and number of years' experience (at ITAC) of staff.

The high level of experience of staff is positive for maintaining continuity and institutional memory. It is also important, as some of the skills needed in ITAC work are learnt on the job. However, the Chief Economist of ITAC has suggested that a possible disadvantage of excessive staff longevity is that at some times staff may become 'too rigid'. They tend to use an 'experience-based' approach in analysing the cases rather than 'technical-based' methods, which may hamper new approaches to assessing tariff cases (Interview with ITAC Chief Economist, 2013). In the view of the authors, this observation is not necessarily an argument against experience or staff retention per se, but rather highlights the need for ongoing training and up-skilling. This includes the training of even experienced personnel with current technical methodologies as necessary and appropriate. This is discussed further in section 5 . 


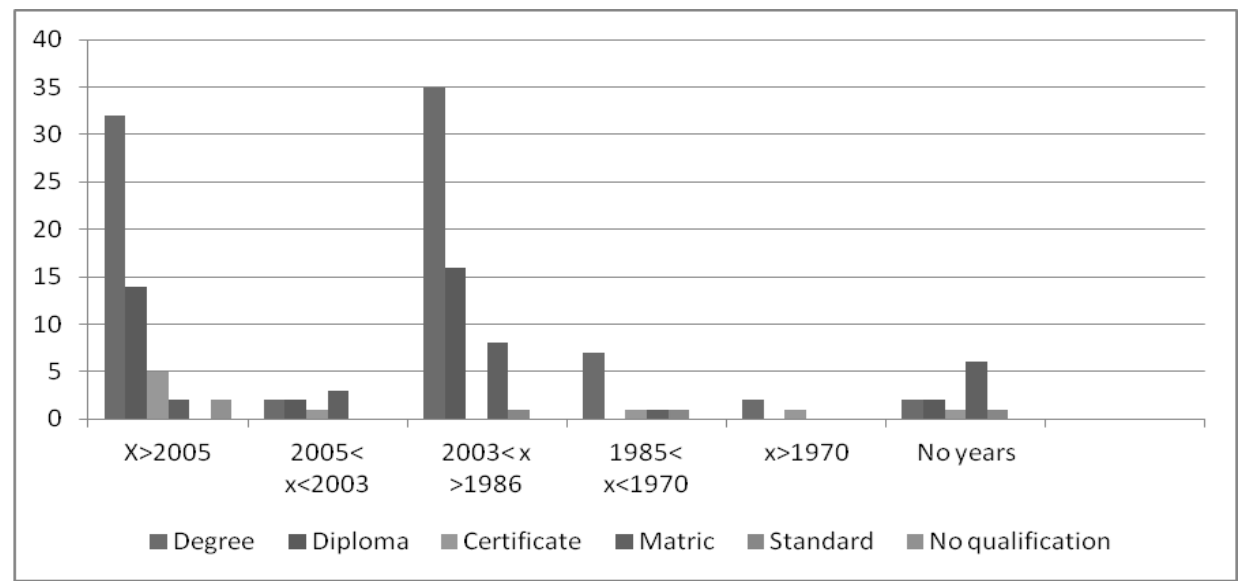

\section{FIGURE 1: Comparing experience across qualifications of ITAC staff}

\section{Source: ITAC Senior Manager: Human Resources, 2013}

Note: $x$ indicates the starting date of the employees.

The Chief Commissioner and senior management of ITAC identified a few human resource-related issues that they believe need review. Firstly, they consider the staff complement to be too small. They would want the creation of additional positions, which they believe would assist in speeding up the investigation process. Secondly, the Chief Commissioner and senior management put forward a view that a number of important positions at ITAC are 'undergraded' relative to equivalent positions at the DTI and elsewhere, which poses a problem for staff retention. Thirdly, and related to the aforementioned point, staff vertical mobility within ITAC is limited in that employee growth and promotion prospects are constrained once they reach a certain level, for example the level of Senior Managers. In a contrary view, ITAC's Senior Manager for Human Resources has stated that staff turnover at ITAC is not a big threat (Mndebela, 2014). In support of this she indicates that 'only [29] employees ... terminated their services [from 1 April 2012 to date] and the reasons for termination of service are different'.

As regards the reasons for staff turnover, of the 29 staff that left ITAC during the period April 2012 - March 2014 the contract came to an end in five cases, one staff member passed away, one was pensioned, one left ITAC because of misconduct and 21 resigned. TABLE 4 summarises the departure of ITAC staff (for whatever reason) during this period, by level. The levels range from administrative assistants at level 2 to General Manager and above at level 14.

According to the Senior Manager for Human Resources, different reasons were given for resignations but most of the employees left ITAC for better work opportunities and career advancement (Mndebela, 2014). Some of the reason given for those who resigned is lack of employee growth prospects within ITAC. She indicates that 'according to our exit trend analysis report, none of the employees who were interviewed during their exit cited under-grading of positions as their reasons for leaving ITAC'. The Senior Manager for Human Resources argues that salary grading is not a problem, since ITAC is using the Equate System that is used by all government entities to grade positions and that the policy framework and guidelines governing job evaluation are those that are provided by the Department of Public Service and Administration, as with other government departments. 
TABLE 4: Departure of ITAC staff, by level, from 1 April 2012 to date

\begin{tabular}{cc}
\hline Level & Number \\
\hline 14 & 2 \\
13 & 2 \\
12 & 4 \\
10 & 7 \\
9 & 1 \\
7 & 2 \\
6 & 1 \\
3 & 2 \\
2 & 2 \\
\hline Temporary and interns & 6 \\
\hline Total & 29 \\
\hline
\end{tabular}

Source: Derived from information provided by ITAC by email

A rather high proportion of the staff departures were at senior levels, as shown in table 4. In particular, six Senior Investigators (at level 10) departed during this period, of whom five resigned. This is potentially of concern given the importance of these staff in the core work of ITAC, as well as the fact that significant skills for these roles are acquired on the job.

There appears to be a discrepancy between the view of the Senior Manager for Human Resources and her interpretation of the exit interview data, and the view put forward by the Chief Commissioner and other member of senior management, regarding whether under-grading of positions is a factor in the turnover of ITAC staff (especially senior staff). However, it is worth noting that implicit in the reason of 'better work opportunities and career advancement' cited by the Senior Manager for Human Resources could potentially be an issue of under-grading of positions, even if that is not explicitly cited as such in the exit interviews. That is, staff may hypothetically be able to obtain better opportunities elsewhere if their positions at ITAC are 'under-graded'. This issue is discussed further in section 5.

In terms of stakeholder perceptions, both the Paper Manufacturers Association of South Africa (PAMSA) and Sappi have pointed to what they consider to be insufficient capacity at ITAC. An example cited was that at one point ITAC had to change the dates three times for verification in the case of A4 paper, which in the view of the party is indicative of capacity problems. Sappi also suggested that at times ITAC shows some inconsistencies, which they believe points to lack of experience or the use of inexperienced staff for verification processes. The Chief Executive Officer of the South African Poultry Association (SAPA) has argued that investigation teams need to understand the dynamics of the market, and has recommended that they should learn more about the sector they will be investigating before starting their investigation. SAPA also raised an issue of what they regard as inadequacy of skills in some cases, in particular among staff who do company visits for verification, and have recommended that these staff need continual up-skilling. 


\subsection{ITAC skills development and capacity-building}

ITAC has a Skills Development Plan as well as a Workplace Skills Plan, which it submits to the Department of Public Service and Administration, and with which it needs to comply every year. ITAC also submits an Annual Training Report every year. ITAC undertakes a range of staff training programmes. ITAC has trained a total of 117 staff. Twenty-eight economists were trained in areas varying from customs clearing and project management to advanced computer courses. Human resources staff were trained in skills ranging from project management and planning to labour relations. There is also ongoing 'on-the-job' training. Furthermore, internship programmes were introduced in 2012.

Specialised training has also been outsourced on tender and developed specifically to meet the needs of ITAC. There is a two-week intensive certificate-level course, leading to a Certificate in Trade and Financial Analysis, which has been co-developed by DNA Economics and the University of the Witwatersrand. The basic aims of the course are to equip ITAC investigators with a common level of understanding of key economic and accounting concepts and to provide them with the necessary tools and data to conduct comprehensive economic analysis of trade policy interventions.

Policy recommendations concerning ITAC human resources and capacity-building are put forward in the next section.

\section{DISCUSSION AND POLICY RECOMMENDATIONS}

\subsection{Institutional location of tariff-setting}

Locating the roles of tariff investigations and of making recommendations as to tariff changes in a semi-independent institution such as ITAC is one possible institutional arrangement. An alternative is to locate these roles directly inside a government department, for example as a directorate of the DTI. Brazil is an example of the latter case, as discussed in section 2.

The decision as to the most appropriate institutional location for these functions depends in part on a perspective as to how tariff-setting fits into broader economic policy, as well as on the types of the considerations that should inform tariff decisions. If tariff-setting is viewed as a technical economic process that should be purely objective in nature, then it could be considered appropriate to locate this in an independent institution outside of government. Conversely, if tariff-setting is viewed as inherently political, with no right answers but with winners and losers associated with every possible outcome, then it could be considered appropriate to locate it directly within a government department. Such an arrangement could also have a benefit of allowing for public policy objectives to be directly translated into tariffsetting without intermediation.

The South African institutional arrangement could be understood as attempting to achieve some sort of balance in this regard. On the one hand, public policy is brought into the orientation and work of ITAC in several important ways. Senior appointments are made by government. The institution as a whole is accountable to government. There is ongoing communication of government's strategic economic objectives to ITAC. Crucially, ITAC's tariff recommendations are subject to approval of the Minister of Trade and Industry. It is noteworthy that the Minister does not always approve ITAC's recommendations, indicating the active role played by the 
Minister in ensuring that government's policy objectives are consistently at the forefront. In the authors' assessment, however, there currently does not seem to be a disjuncture between ITAC's work and government's policy objectives, and ITAC does appear to be advancing these objectives.

On the other hand, ITAC's location outside of government does give it a degree of distance and independence. The role of the part-time Commissioners, who are mostly employed outside of government, brings an additional measure of independence.

There could be advantages and disadvantages to locating the functions of ITAC directly within a government department. We raise this issue here for further debate. In the view of the authors, there are not compelling reasons for altering the current institutional arrangement at present.

\subsection{Position of ITAC under two line departments}

The current institutional setting is essentially that ITAC falls under the Minister and Department of Economic Development, but the mandate around trade policy and any changes therein derives from the Minister of Trade and Industry, with such changes being communicated through Economic Development, and with the Minister of Trade and Industry having the power to take final decisions on tariffs. The positioning of ITAC under two line departments, while understandable, is not ideal. On the one hand, ITAC is central to South Africa's trade policy, which falls squarely under the DTI. On the other hand, the EDD is responsible for other economic regulators, whose close co-ordination with ITAC is important, as well as the broader development and co-ordination of economic policy within which ITAC operates.

Some stakeholders interviewed, such as PAMSA, have expressed dissatisfaction with this arrangement and believe that it may delay processes. However, the view from the interviewee from the EDD is that, while the arrangement is slightly cumbersome and may lead to slower communication in certain instances, it is basically working. The arrangement also has some benefits. One of these is enhanced policy co-ordination, and related to this the communication of government's strategic economic priorities and refraction of these in ITAC's work. The EDD has also been able to link ITAC up with the Industrial Development Corporation (IDC) where ITAC is working on a particular sector that the IDC has existing specialised knowledge and research on.

Consideration could be given to simplified lines of accountability while ensuring the coherence of trade policy (including coherence between tariff-setting and other aspects of trade policy), coherence between trade and industrial policy, and optimal coordination between ITAC and other economic regulators.

\subsection{Increased co-operation with other economic regulators and relevant institutions}

It does not appear that there is sufficient communication and co-operation between ITAC and other economic regulators with related mandates. An obvious case is between ITAC and the Competition Commission.

PAMSA has also expressed the need for closer relationships between ITAC, the EDD, the DTI and SARS in order to speed up the implementation of decisions. They raised the following example: the imposition of a tariff on a certain line may see traders diverting their products to another 
product line with a lower tariff, which can be partly mitigated by the relevant departments working closely with each other.

ITAC acknowledges that there is scope for increased co-operation with other economic regulators, in particular with the Competition Commission. The Chief Commissioner of ITAC noted the example of the poultry sector, where ITAC increased the duty while the Competition Commission raised the issue of the anti-competitive behaviour in the sector, as an illustration of the need for increased co-operation. ITAC plans to improve communication and co-operation with the Competition Commission.

\subsection{Strengthening of reciprocity requirements}

ITAC may include reciprocity requirements as part of its recommendations on tariffs. These measures can require companies that are in some way 'beneficiaries' of a particular tariff decision to reciprocate with specific commitments of, for example, investment or employment.

Reciprocity agreements can be a key tool of industrial policy and an important link between trade and industrial policy. They are essential for ensuring that gains from tariff protection do not just become windfall gains that are privately accrued by individual companies, but rather become broader economic gains that contribute to national economic objectives such as increasing employment. Reciprocity agreements can be understood as part of 'rent management' in the sense of the state managing rents that would otherwise be captured by private agents. The fact that ITAC has the legal power to pursue reciprocity agreements is a powerful policy tool that, needs to be fully utilised.

A view expressed by the interviewee from the EDD is that ITAC is not always strong enough in negotiating sufficient commitments from industry and in pushing industry hard enough. In some instances industry may present a plan to ITAC for what it would have done anyway, without really making any substantial new commitments directly linked to the gains from tariff protection.

Negotiating stronger reciprocity commitments needs specific types of skills, notably in negotiations. Training could assist in this regard, but it may also require the employment of people who already have those sorts of skills and mentality. This needs to be complemented with strong economic analytical skills in order to assess what sorts of commitments from industry are feasible, and to distinguish between what industry may have done in any event and net new commitments.

\subsection{Duration of tariff investigations}

The timeframes taken in completing tariff investigations are important, for several reasons. Firstly, where domestic industry is under pressure from imports it is essential that any decisions to protect industry through tariff increases be made speedily in order to minimise negative effects on production, production capacity and employment. Secondly, domestic and international economic conditions that are germane to tariff decisions change rapidly, so the longer the duration of a tariff investigation the less accurate the economic information upon which the decision is eventually based is likely to be. Thirdly, while tariff investigations are in progress, there is uncertainty for business, which may hamper investment.

Concerns have been raised by some stakeholders interviewed for this research about the length of time taken in ITAC tariff investigations. According to these parties, the time between companies submitting their information on the template provided by ITAC and ITAC coming for 
company visits is too long. SAPA is of the view that the time between ITAC completing its investigation process and the time when the Minister announces the decision is excessive. PAMSA raised a concern that sometimes it takes quite long for a decision to be made, and all the while the industry is suffering. They cited the example of it taking two years for the application for a tariff increase on an A4 bond paper tariff to be heard. Another challenge which has been noted by parties is with regard to scheduling of the next meeting from the day of visit, which has been said to be too long. For example, regarding the A4 paper verification, the visit was done in December and next meeting was convened only in February. The interviewee from EDD also mentioned that, while ITAC has succeeded in reducing the time of investigations over the past five years, there is still room for improvement in this regard.

A related concern raised by companies is around the implications of changing market dynamics in the course of cases. While cases are underway there are relevant changes in exchange rates, input costs such as electricity prices, and so on. This means that if ITAC asks for resubmission subsequent to such changes it will mean restarting the whole process in data collection, since market-related information will have changed. Revising the figures can be costly and time consuming for the firms concerned.

ITAC recognises the importance of concluding tariff investigations within as short a time period as possible. Progress has been made in reducing the timeframes of tariff investigations. Currently about $75 \%$ of investigations are concluded within the required timeframes (Tsengiwe, 2014).

There is still room for improvement, in particular in terms of ensuring that all investigations are completed within the stipulated timeframes. Of course, this cannot compromise the rigour of investigations or the following of due process.

Enhancing capacity within ITAC could be one way of speeding up investigations. This capacitybuilding could take the form of increasing the number of staff in specific 'bottle-neck' areas that may be delaying or prolonging the pace of the investigations. It could also take the form of up-skilling of existing staff so as to increase productivity and thence the speed of investigations.

\subsection{Part-time Commissioners}

Part-time Commissioners play an important role at ITAC. One aspect of this lies in bringing a fresh and 'independent' perspective on ITAC's recommendations before these are brought to the Minister. This can improve the rigour and quality of ITAC recommendations. The fact that recommendations have been subject to this additional layer of 'independent' scrutiny can also be of relevance in any subsequent legal challenges.

The part-time ITAC Commissioners come from a range of backgrounds and bring a diversity of skills, experiences and perspectives. This seems to be a positive feature, and the authors' impression is that this part of the organisation is working well.

There may be scope for additional specialised capacity-building among the part-time Commissioners. Given their different backgrounds, some may for example lack legal expertise, while others may lack knowledge of trade economics. While collectively they possess all the requisite skills, each individual Commissioner ideally needs some knowledge in all the core areas of ITAC's work. 
ITAC has run some training for incoming Commissioners, but this does not appear to be conducted on a regular basis. A thorough analysis of the needs in this regard could inform what additional training might be needed to address gaps in knowledge or skills among Commissioners. Such training could for example be divided between those needing additional training in the legal and economic domains. Training could also be undertaken at different times on different topics, including at increasing levels of advancement, rather than being once-off. Of course, it needs to be recognised that part-time Commissioners have full-time employment elsewhere and hence are likely to have limited time available for training.

\subsection{Joint capacity-building among the economic regulators}

ITAC has identified its primary weakness in current capacity as being in the detailed analysis of corporate financial information, and has identified this as an area in which capacity-building could be needed. ITAC takes the view that this expertise is highly specialised and specific to their particular role, such that any training in this area would need to focus on ITAC specifically.

The authors share ITAC's view as to the importance of ITAC having strong in-house capacity in analysing corporate financial information. Without this capacity, ITAC staff would be unable to make rigorous and accurate assessments of companies' financial positions. This is essential for assessing the potential impact of alternative tariff decisions on companies, and for weighing up the validity and veracity of companies' arguments in this regard.

However, our view is that the need for these skills is not restricted to ITAC but is shared by several other economic regulators. In particular, the Competition Commission, the National Energy Regulator of South Africa (NERSA) and the Independent Communications Authority of South Africa (ICASA) all require such skills in order to play their roles effectively. For instance, the Competition Commission must analyse detailed company financial information in order to make assessments of costing and pricing, and the presence of uncompetitive practices and the effects thereof. NERSA must make assessments about appropriate price structures in the energy sector based in part on financial information of the companies involved.

This suggests that there is scope for some common training where particular skills are required by more than one of the economic regulators. Instead of the regulators procuring such training individually, this could be jointly provided, either using existing in-house capacity or external training providers (or a combination thereof). This would reduce the costs of such training. It could also provide for a fruitful interaction among staff who are working on related issues or using similar skills in the different economic regulators. Naturally, in order to address the particular needs of individual regulators there may be a need for further specialised training in addition to the common training.

Based on the needs identified by ITAC, training in financial accounting - specifically the reading and critical analysis of companies' financial information - presents itself as one strong possibility for common training. This could be done jointly with economic regulators such as NERSA, the Competition Commission and ICASA. Common training in this area could be supplemented by advanced specialised training in this area, tailored to the specific needs of the individual regulators. 


\subsection{In-sourcing of research, strengthening of research capacity and strengthening of economics capacity}

ITAC currently utilises both in-house and outsourced research. Most of the research activities at ITAC are done by the Policy and Research Unit. A limitation facing ITAC is an organisational structure that does not allow it to employ more staff to speed up the research process. ITAC has far fewer researchers and less research capacity than for example the Competition Commission.

Much of ITAC's research has hitherto been contracted out. According to the Chief Economist it also typically usually make use of consultants to verify company information such as input costs and Free on Board (FOB) prices.

ITAC requires rigorous and reliable research as part of its investigations and to contribute to informing its findings. ITAC also provides research-based technical and policy analysis to the EDD and DTI in relation to the work of ITAC. For instance it is required to give feedback to government on jobs that could be created after the implementation of tariff changes to specific sectors, and research findings on whether the reciprocity commitments have been met.

ITAC also conducts impact assessments in order to provide feedback to government as to whether the support has led to changes in employment, investment, value addition and competitiveness. These economic variables are assessed for three years before and three years after the intervention. It also reviews tariff investigation guidelines to align these with government policy. Ultimately from the research output it should advise on the alignment of ITAC policies, regulation, guideline and practices to the New Growth Path (NGP), Industrial Policy Action Plan (IPAP) and South Africa's Trade Policy and Strategic Framework (SATPSF).

One issue pertaining to ITAC's research is the extent to which it should be externally commissioned as opposed to conducted in-house. Commissioning research from outside an organisation does have certain advantages. These include the opportunity to engage skills that are not available within the organisation and that are unnecessary or unaffordable for an organisation to employ internally on an ongoing basis.

However, excessive reliance on outsourced research has several drawbacks. Firstly, it does not facilitate skills and knowledge being built up within an organisation. Secondly, an outside service provider may not share the same understanding of policy and views of the organisation, which can have implications for the types of methods and assumptions utilised. For example, a private economics research company may have its own views about trade liberalisation, which may differ from government's policy stance, and the consultant company's views could implicitly or explicitly find their way into research commissioned from them. Thirdly, commissioning research externally can be costly, as payments must be made to service providers who are conducting research as a business enterprise.

ITAC has expressed a desire to build up its own internal research capacity. Already, ITAC is doing more research in-house than was previously the case, and the employment of a Chief $\varepsilon$ conomist has assisted in this regard.

The authors are of the view that most research should be conducted in-house, with outsourced research being the exception. This is likely to imply the need for additional posts to be created. While this would have cost implications, these could be offset against cost savings from a reduction in commissioned research. Improving research capacity could also potentially 
strengthen the quality of ITAC investigations and recommendations and enhance its robustness to legal challenges.

Closely related to the above is the need for an overall strengthening of research capacity and improving the quality of research. The interviewee from the EDD, who is also a part-time Commissioner at ITAC, suggested that there could be more rigour and accuracy in ITAC's research work. This is particularly in the context of ITAC's decisions now being potentially more controversial than previously, due to shifts in their mandate. These changes mean that ITAC's work is compelled to be more rigorous and of higher quality. One suggestion which he made in this regard is that work done by junior staff needs to be subject to stronger screening and quality control by middle and senior staff.

A related issue is the need to increase ITAC's economic capacity in particular. Our sense is that ITAC's capacity is currently stronger on the legal side than on the economic side. The appointment of a Chief Economist has significantly improved ITAC's economic capacity compared to previously. However, it is arguably still not strong enough given the nature of the work which ITAC is involved in and the economic capacity of parties (and their consultants) that appear before ITAC. Excellent in-house economic capacity is essential for ITAC to be able to evaluate the validity and veracity of economic evidence presented before it, to reach its own judgements, and to be able to assess the economic impact of alternative decisions. It would also be helpful in obtaining stronger reciprocity commitments from companies, as discussed earlier.

ITAC has begun conducting impact assessments, and these appear to be becoming an increasingly important part of ITAC's economics and research work. Impact assessments are not easy to undertake. If not done accurately, they are virtually worthless (and may actually be damaging if inaccurate or misleading). The skills needed for doing impact assessments are highly specialised and are not necessarily fully taught in the standard academic training of economists. Concrete evidence-based empirical analysis is fundamental. ITAC has already made progress in developing a methodology for impact assessments, although as acknowledged by the Chief Economist this still needs further improvement.

\subsection{Strengthening of inspections capacity}

Company inspections form an important part of ITAC's work. One aspect of this is ensuring that companies are indeed fully complying with requirements, such as compliance with labour legislation and Bargaining Council agreements (where relevant). Tying companies that are benefiting from tariff protection to such requirements is a good way of improving compliance with the laws of the land. The efficacy of this, however, depends on the degree to which such requirements are enforced in practice. Inspections are essential in this regard.

Views have been expressed by some stakeholders that ITAC's inspection capacity is currently not strong enough. Inspectors need to have a clear idea of what they are looking for and how to obtain or ascertain it. It is unclear whether improving ITAC's inspections could require additional staff, additional training of existing staff, or simply better management and organisation of existing staff.

\subsection{Review of the grading of ITAC staff levels}

ITAC management has raised a strong concern around the grading of positions within ITAC. The view of the ITAC Chief Commissioner and senior management is that a number of important 
positions in the ITAC staff structure are graded at too low a level, in particular relative to the DTI and related institutions. From their perspective, this is a significant cause of staff turnover and the loss of important skills that have been developed through experience and capacity-building at ITAC. A different view was however expressed by the Senior Manager for Human Resources, as discussed earlier.

Staff turnover at managerial and professional levels is of concern given the importance of onthe-job training at ITAC. Even if suitably qualified replacement candidates are found, additional time and training are required to render them proficient in the required competencies. Undergrading of positions may indeed be a problem at ITAC, but it must also be recognised that the staff of an organisation may have a direct interest in the upgrading of positions, hence an independent review would be valuable.

It is recommended that an organisational review of the ITAC staffing structure take place. Of particular importance is to benchmark positions at ITAC to positions at similar regulatory bodies and the DTI, in terms of inter alia the levels of skills required and the responsibilities entailed in specific positions. Such a review could also systematically examine the reasons for the departure of senior staff at ITAC, utilising exit interviews among other sources. This could be informative as to the reasons for turnover and the extent to which inappropriate grading of positions is a factor in this regard. The findings of such a review could provide a basis for identifying the merit, if any, for regrading of specific positions at ITAC.

\section{Acknowledgement}

This article draws on research undertaken as part of the Regulatory Entities Capacity Building Project, with funding from the South African government's Economic Development Department. The authors thank all those who made themselves available for interviews and provided valuable information and insights.

\section{LIST OF REFERENCES}

Almeida M. \& Schneider, B.R. (2013). Globalization, democratization and the challenges of industrial policy in Brazil. In E. Campos, W. Lim \& R. Locke (eds.) Industrial Policy. Washington, DC: World Bank.

Department of Trade and Industry (DTI). (2010a). A South Africa Trade Policy and Strategy

Framework. Pretoria: Department of Trade and Industry.

Department of Trade and Industry (DTI). (2010b). Industrial Policy Action Plan (IPAP), 2012/13-

2014/15. Pretoria: Department of Trade and Industry.

Economic Development Department (EDD). (2011). The New Growth Path: Framework. Pretoria: Government of the Republic of South Africa.

Edwards, L. \& Lawrence, R.Z. (2008). South African trade policy matters: Trade performance and trade policy. Economics of Transition, 16(4), pp. 585-608.

Government of the Republic of South Africa. (2002). International Trade Administration Act No. 71 of 2002.

Government of Pakistan. (2011). Trade Policy Review. 
International Trade Administration Commission of South Africa. (2013). Annual Report 2012-2013. Pretoria: International Trade Administration Commission of South Africa.

Ministry of Development, Industry and Foreign Trade: www.mdic.gov.br

Mndebela, L. (2014).e-mail, 12 March 2014, Imndebela@itac.org.za

National Tariff Commission, www.ntc.gov.pk

Obinyeluaku, M. (2014). e-mail, 14 March 2014, mobinyeluaku@itac.org.za

Pursell, G., Khan, A. \& Gulzar, S. (2011). Pakistan's trade policies: future directions. International Growth Centre, report prepared for the Planning Commission of Pakistan.

Sally, R. (2012). Indian trade policy after the crisis. South Asia in the New Decade: Challenges and Prospects, 225.

Tariff Commission, www.tc.nic.in

Tregenna, F. (2011). A new growth path for South Africa? Review of African Political Economy, 38(130), pp. 627-635.

Tregenna, F. (2012). Sources of subsectoral growth in South Africa. Oxford Development Studies, 40(2), pp. 162-189.

Tsengiwe, S. (2014). e-mail, 5 June 2014, stsengiwe@itac.org.za. 
Tregenna \& Kwaramba

\section{APPENDIX: LIST OF INTERVIEWEES}

The following persons were interviewed for the purposes of this research.

Mr S Tsengiwe, Chief Commissioner, ITAC, 3 December 2013

Ms Z Xabendlini, Senior Manager: trade Remedies II, ITAC, 3 December 2013

Ms R Theart, Senior Manager: Tariff Investigations I, ITAC, 3 December 2013

Mr T Chauke, Director, DTI, 3 December 2013

Prof S Roberts, Director, Centre for Competition, Regulation and Economic Development, 12

December 2013

Ms L Mndebela, Senior Manager: Human Resources, ITAC, 17 December 2013

Dr M Obinyeluaku, Chief Economist, ITAC, 17 December 2013

Ms J Molony, Chief Executive Officer, PAMSA, 24 January 2014

Mr P Bortolon, Business Manager Paper, Sappi, 24 January 2014

Mr L Kelvin, Chief Executive Officer, SAPA Chief Executive Officer, 31 January 2014

Mr $\varepsilon$ Vlok, Trade Specialist, Economic Development Department and Part-time Commissioner at ITAC, 14 March 2014 